Teaching about Television 


\title{
Teaching about Television
}

\author{
Len Masterman
}

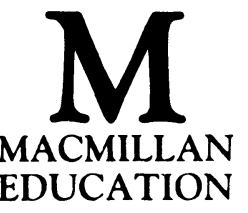


All rights reserved. No reproduction, copy or transmission of this publication may be made without written permission.

No paragraph of this publication may be reproduced, copied or transmitted save with written permission or in accordance with the provisions of the Copyright Act 1956 (as amended).

Any person who does any unauthorised act in relation to this publication may be liable to criminal prosecution and civil claims for damages.

First published 1980

Reprinted 1982, 1983 (twice), 1984, 1985, 1987

Published by

MACMILLAN EDUCATION LTD

Houndmills, Basingstoke, Hampshire RG21 2XS

and London

Companies and representatives

throughout the world

British Library Cataloguing in Publication Data

Masterman, Len

Teaching about television.

1. Television broadcasting - Study and teaching

I. Title

301.161 HE8700.6

ISBN 978-0-333-26677-9 ISBN 978-1-349-16279-6 (eBook)

DOI 10.1007/978-1-349-16279-6 
For Paula and Edith 


\section{Contents}

Acknowledgements

Introduction by STUART HOOD xiii

1. Television, Film and Media Education 1

1. The present situation 1

2. Film studies 2

3. Media studies 3

4. The case for television studies $\quad 7$

a. The field of study $\quad 8$

b. The mode of enquiry 11

c. Core concepts and principles 11

d. The importance of television studies 12

e. 'Appreciation' and 'discrimination' 13

2. The Methodology and Organisation of Television Studies 21

$\begin{array}{ll}\text { 1. The significance of methodology } & 21\end{array}$

2. Television studies: some principles of organisation

3. Organisation and methodology: practical difficulties 29

a. Marking and assessment $\quad 29$

b. Discussion problems $\quad 34$

c. Organisational minutiae $\quad 36$

3. Towards Teleliteracy - 1: Exercises in Perception and non-verbal Communication

1. Some problems of perception 40

a. Exercises in perception $\quad 40$

b. Visual games and puzzles $\quad 41$

2. Non-verbal communication 43

a. Introduction 43

b. Visual comprehension: a conceptual framework 44

c. Methodology 46 
d. Introducing non-verbal communication in the classroom 47

e. Eye-contact and facial expression 48

f. Touch and body contact $\quad 50$

g. Kinesics 52

h. Positional communication (proxemics) 53

i. Physical appearance 55

j. Analysing objects 56

k. Analysing photographs 59

1. Conclusion: a note on texts 60

4. Towards Teleliteracy - 2: Beginning Television Analysis and Introducing Television Concepts

1. Iconographic analyses: Top of the Pops and Gardeners' World

a. Top of the Pops 62

b. The world of Gardeners' World 65

c. Top of the Pops: what was learned? 66

2. Analysing title sequences $\quad 67$

3. Introducing genre 68

4. Television cartoons 68

a. Comic strips: narrative sequencing, narrative
prediction and cloze exercises

b. The Flintstones book 69

c. Television cartoons: hand out $\quad 70$

5. Establishing Questions (Young Scientists of the Year) 72

a. Young Scientists of the Year: hand out 74

5. Television News 77

1. Why teach about television news? 77

2. News simulations 78

a. Front Page and Radio Covingham 78

b. Television News: an original simulation 79

c. The value of simulation: some notes 81

d. Case study: television news simulation played at Liverpool University 84

3. Analysing televised news in the classroom: comprehensive school pupils' responses $\quad 91$

4. Analysing television news: other possibilities 94

a. News selection and values $\quad 94$

b. Bias and balance in news programmes $\quad 98$

c. The news as show 106

d. News as reassurance 107

$\begin{array}{ll}\text { e. Visual codings } & 107\end{array}$

$\begin{array}{ll}\text { 5. Conclusion } & 108\end{array}$ 
6. Football on Television 109

1. Introduction 109

2. Teaching about televised football: some difficulties 109

a. The reactions of other teachers 109

b. Organisation and planning 110

3. The Cup Final: suggested approaches 111

a. Pre-publicity material 112

b. Introductory or credit sequences 114

c. Cultural codes 114

d. Stereotyping of teams and players 114

e. Football and the star system 115

f. Visual style 116

g. Soccer experts and panels 116

4. The Cup Final: other approaches 117

a. Appropriation and ritualisation 117

b. The nature and function of support programmes 119

5. Conventional football coverage $\quad 120$

7. Television Specificity and Programme Planning: Two Participatory Exercises 122

1. Television specificity 122

2. Programme planning: a simulation 126

a. Part one 126

b. Part two 132

$\begin{array}{ll}\text { 8. Practical Television Work } & 137\end{array}$

9. Aspects of Television 144

1. The interview 144

a. 'Starters': simulating interviews 144

b. Interviewing suggestions: hand out 147

c. Analysing television interviews $\quad 150$

2. Television documentary 151

a. Introducing documentary 151

b. Looking at documentaries 153

3. Some approaches to television comedy 154

a. Introduction 154

b. Television comedy genres 155

c. Resources 155

d. Surrealism and humour: some surrealist games 158

e. Realism and social attitudes in situation comedies 159

f. Stand-up comedians 163

4. Mediated education 166

a. Mediated science: Tomorrow's World 167 
b. Tomorrow's World: hand out

c. Burke's master-class: The Burke Special 170

d. Education as inquisition: Mastermind 172

5. 'Classic' serials

10. Social, Political and Aesthetic Education through Television

1. Social education

a. Group awareness 177

b. Teacher participation $\quad 177$

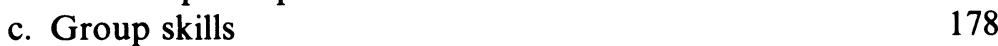

$\begin{array}{ll}\text { d. Observation and communication } & 178\end{array}$

e. Pupil participation and control 178

2. Political education 179

$\begin{array}{ll}\text { a. Introduction } & 179\end{array}$

b. Implicit political education $\quad 180$

c. The political dimensions of social and aesthetic education

d. Imagining alternatives 181

e. Political issues and events 181

$\begin{array}{lr}\text { f. The significance of structures } & 182\end{array}$

g. The process of political education 183

3. Aesthetic development 183

a. Posing the question 183

b. Eliciting a response $\quad 184$

c. The process of aesthetic development 185

4. Social, political and aesthetic education: a final note 188

Appendix 1 Periodicals of Interest to the Television Teacher 190

Appendix 2 Organisations with an Interest in Television Education

Appendix 3 CSE Mode III Syllabus for Television Studies East Midlands Regional Examination Board 193

Notes and References $\quad 196$

Select Annotated Bibliography 205

Index 219 


\section{Acknowledgements}

To:

The IBA. Without the support of one of their excellent Research Fellowship awards, this book would never have seen the light of day. The book does not, of course, necessarily represent the views of the Authority.

Charles Mayo of the IBA for all of his patience, co-operation and help.

Professor Stuart Hood, for his continual advice and active support.

Ed Buscombe, Manuel Alvarado and Bob Ferguson for their interest in my work and their generous and helpful comments upon early draft material.

Dr John Daniels, Wyn Williams and Dr Paula Allman, three great educators to whom I have a general indebtedness; I have learned more from them than from a library of books.

Adrienne Edwards, Pat Hughes, Audrey Eaton, Jill Cleaver and Marian Anderton, who have provided impeccable secretarial assistance in the face of indecipherable handwriting.

John Wightman for technical and photographic assistance.

The following friends and colleagues, who have all in different ways influenced this book:

Dr John Baggaley
Andrew Bethell
Terry Dolan
Gillian Dyer
Mike English
Richard Exton
George Foster
Brian Glover
Felicity Grant
John Hardcastle
Noel Hardy

Dr John Baggaley Andrew Bethell Terry Dolan Gillian Dyer Mike English Richard Exton Brian Glover Felicity Grant Noel Hardy Colin Harrison Heather Hillier Vale Humble Douglas Lowndes Andy Mead Hugh Morris Chris Mottershead Bob Osgerby Alan O'Shea John Thompson Professor Ted Wragg 
All of the pupils who participated in my television classes, and who tolerated my mistakes. My debt to them - whether their work is represented here or not - is an obvious one.

My wife, Paula, for her unstinting support and superhuman understanding, and for clarifying many of my ideas for me over a late-night pint.

To all, my gratitude and thanks.

The courtesy of the following is also acknowledged for permission to use copyright material from these sources:

S. M. Jourard and the Cambridge University Press for Figure 1 from the British Journal of Social and Clinical Psychology, vol. 5 (1966) p. 229; Dr Barnardo's for Plate 1; TV Times for Plate 3; John Timbers and Radio Times for Plates 2 and 4; TOPIX (Thomson Regional Newspapers Ltd) for Plate 5; Michael Simons and Cary Bazalgette, with Simon Clements and Andrew Bethell, for Plates 6, 7, 8, 9; Richard Hoggart and Chatto and Windus Ltd for Speaking to Each Other (i) About Society; Sheed and Ward Ltd and Penguin Books Ltd for Pedagogy of the Oppressed by Paulo Freire; Eamonn McCann for 'The British Press in Northern Ireland'; Dennis Potter and New Statesman for 'Lost Horizons'; Richard Collins and the BFI for Television News; Tom Burns and Macmillan, London and Basingstoke, for The BBC; John Dearlove and Index on Censorship for 'The BBC and the Politicians'; Times Newspapers Ltd for my own pieces on 'The Burke Special' and 'Mastermind'; and, with Albert Hunt, for 'When to Say No'; Trevor Griffiths and Faber and Faber Ltd for Comedians; Random House Inc. for Culture Against Man; Dr Desmond Morris and Jonathan Cape Ltd for The Naked Ape. 


\section{Introduction}

\section{by Stuart Hood}

Why teach about television?

One answer is that television can be used as a substitute for literature. If pupils read little and watch television instead, some teachers argue, then perhaps television may provide surrogate material for 'appreciation' and for content analysis. Others see in the use of television a means of self-expression or self-discovery; it has to be added, however, that the first enthusiasm for electronic equipment has waned somewhat. Others still, aware of the growth of media studies at centres of higher education, respond by teaching about television in the context of the wider study of other media: film, the press, photography, advertising. It is part of that inevitable process whereby what has been incorporated in the syllabus at a higher level finds its way down into the secondary schools. Len Masterman belongs to none of these tendencies. What inspires him to propose that we teach children about television is the view that television has replaced film as the most important mass medium; the knowledge that children, who may go to the cinema twice a year, view for more hours per week than they spend in school; and the conviction that these children can only benefit from an understanding of the medium from which they will derive, over their lives, the greater part of their information and entertainment.

To those who object that much of television is trivial and suggest that school time might be better employed than discussing, for instance, situation comedy or football on television, Masterman replies that, in crucial ways, what is said on television is less important than how it is said. What pupils who are taught about television should become aware of is that television has a language of its own with which values are suggested, attitudes reinforced and statements conveyed about society, the family, male-female relationships. The language is a complex one consisting not only of words but of gestures, the way a shot is framed, the way opening titles are designed, the way an announcer is dressed, the way a studio is furnished. In short, he sees television as a conveyor of ideology - an ideology which is the more effective, the less easy to challenge, if the viewer is convinced that the medium is transparent. For ideology on television depends to a large degree on the 
impression that its images are as apparently unmediated as water, gas or electricity appear to be when we turn on a tap or switch on a light.

Granted the desirability of teaching about television, how does one set about it? Are the concepts basic to a critical theory of the medium - for that is what Masterman is propounding - not too sophisticated for school children who will not necessarily go on to media studies at a polytechnic or university or seek careers in the mass media? They are children who are likely, as he points out, to have been discouraged by the schooling process from believing in their own judgements even when, as is the case with television, they are highly familiar with the subject matter. His answers to the question are concrete - accounts of teaching methods, of exercises in perception and in visual analysis from which teacher and pupils can proceed together to a discussion of the television image and its connotations. The examples he gives of work in this area by children, even when their capacity for formal expression is limited, show that they are-if well taught and rightly encouraged - capable of discussing some of the fundamental questions dealt with in courses on media studies. It is not the subject matter itself that presents the difficulty but the teaching method to be adopted.

One of the pedagogic problems posed by teaching about television is that the children are likely to be familiar with a wider range of the subject matter than the teacher. It is a situation which Masterman sees as capable of positive exploitation in that it permits the teacher to adopt a new and fruitful rolenot that of a source of authority who knows the 'right' answers but of a collaborator in the exploration of an area of knowledge. It is at this point that his views on the importance of television as a subject mesh with his desire to see educational methods radically altered. Masterman believes that many of the techniques practised in schools and taught in colleges of education are calculated not to educate but to cut children off from learning. A system which is based on the retrieval from memory as quickly as possible of the 'right' answer is allied to a competitive ethos of which marks and 'places' are the rewards and expression. It is a system which is calculated to produce in a number of children a block that inhibits learning. Thus for most of my schooldays I was unable to count because of fear and embarrassment at not being able quickly and readily to produce 'correct' solutions and of frustration at not being able to ask what seemed to me to be highly relevant questions; it was only much later that I found that it was possible to think about numbers as one thinks about words. Anyone who has shared this experience will concur with Masterman in opposing competitiveness and what he calls the 'banking' system - the injection of knowledge by the teacher for retrieval at some later date when the proper stimulus is applied - and in opposing an educational system which tends to produce citizens who are as unquestioning about society as they are about the nature and import of the messages they receive each evening on their television screens.

It is important, however, not to fall into extremes of pessimism when 
discussing the television audience. There is probably - this is not an area much explored by audience research - a rather widely diffused scepticism in parts of that audience about what they see on their screens. Men and women workers from Fords who had taken part in mass meetings and voted there were, when interviewed by a student from a London polytechnic, highly critical of the way in which an event in which they had participated was filmed, presented and commented on in television news. It was clear from their responses to questioning that they had a clear understanding of the nature of mediation, of the power of editing and of the importance of the shot. What they lacked were the concepts to allow them to analyse their reactions. What Masterman would like to see is a generation of school-leavers going out into the world already armed with these concepts and accustomed to forming independent judgements not only about television but about the society in which they live. His proposals are innovatory in terms of pedagogy and society, admirably interesting on both counts, and, unlike much current work on the media, they have the virtue of being lucidly written and easy to read. 